\title{
Taxonomy of the genus Ehrharta (Poaceae) in southern Africa: the Setacea group
}

\author{
G. E. GIBBS RUSSELL*
}

Keywords: Fynbos, Capensis, Ehrharta, Poaceae, taxonomy

\section{ABSTRACT}

The Setacea species group in the genus Ehrharta Thunb. is differentiated morphologically by the short first sterile lemma and by inflorescences of fewer than 20 spikelets. The Setacea group is composed of two species, each with subspecies linked by intraspecific intermediates: $E$. rupestris Nees ex Trin. subsp. rupestris; subsp. tricostata (Stapf) Gibbs Russell; subsp. dodii (Stapf) Gibbs Russell and E. setacea Nees subsp. setacea; subsp. scabra (Stapf) Gibbs Russell; subsp. uniflora (Burch. ex Stapf) Gibbs Russell; subsp. disticha Gibbs Russell. All taxa are endemic to the Fynbos vegetation of the south-western Cape Province, with distribution centred in the Caledon degree grid (3419). Parallel trends for plant size and habit, leaf blade width and position, and spikelet size are demonstrated in both species, with similar plant types occurring in similar geographical areas.

\section{UITTREKSEL}

Die Setacea-spesiegroep in die genus Ehrharta Thunb. word morfologies onderskei deur die kort eerste steriele lemma en deur bloeiwyses van minder as 20 blompakkies. Die Setacea-groep bestaan uit twee spesies, elk met subspesies wat deur intraspesifieke oorgangsvorme by mekaar aansluit: $E$. rupestris Nees ex Trin. subsp. rupestris; subsp. tricostata (Stapf) Gibbs Russell; subsp. dodii (Stapf) Gibbs Russell en E. setacea Nees subsp. setacea; subsp. scabra (Stapf) Gibbs Russell; subsp. uniflora (Burch. ex Stapf) Gibbs Russell; subsp. disticha Gibbs Russell. Alle taksons is endemies in die Fynbosplantegroei van die suidwestelike Kaap-provinsie, met die verspreiding in die Caledon-gradevierkant (3419) gesentreer. Parallelle neigings in plantgrootte en -groeiwyse, breedte en posisie van die blaarskyf, en grootte van die blompakkies word in albei spesies aangetoon, met soortgelyke planttipes wat in soortgelyke geografiese gebiede voorkom.

\section{INTRODUCTION}

The genus Ehrharta in Africa comprises 35 species and infraspecific taxa, and has been divided into seven species groups by correlating many characters of spikelet morphology and leaf blade anatomy, as outlined by Gibbs Russell \& Ellis (1987). The leaf blade anatomy in Ehrharta shows a wide range of variation. Characters that normally separate groups at subfamily level elsewhere in Poaceae are here used to distinguish species groups. A detailed treatment of variation within each species and species group is therefore called for. Ellis (1987) demonstrates the variation and discusses the significance of leaf anatomy in the Setacea species group. This paper presents the taxonomy of the species in the Setacea group, and places the morphology of the taxa in context with the anatomy, and with the geographical distribution. The other species groups will be similarly treated in parallel papers in the future.

The seven species groups in Ehrharta may be classified into two major categories, those with the first and second sterile lemmas similar to each other and different from the fertile lemma ( 28 species and infraspecific taxa, in six species groups), and those with the first sterile lemma reduced and glume-like, and the fertile lemma similar to the second sterile lemma (seven species and infraspecific taxa in one species group, the Setacea group, Figure 1). In addition, only in the Setacea group is the number of spikelets always fewer than 20 per inflorescence. Ellis (1987) has distinguished the Setacea group anatomically by the presence of arm cells in the

\footnotetext{
* Botanical Research Institute, Department of Agriculture and Water Supply, Private Bag X101, Pretoria 0001.
}

mesophyll (a character normally of significance at subfamily level in grass classification), the shape of the microhairs, the silica bodies and the intercostal long cells. Detailed morphological and anatomical descriptions of the Setacea group are given by Gibbs Russell \& Ellis (1987).
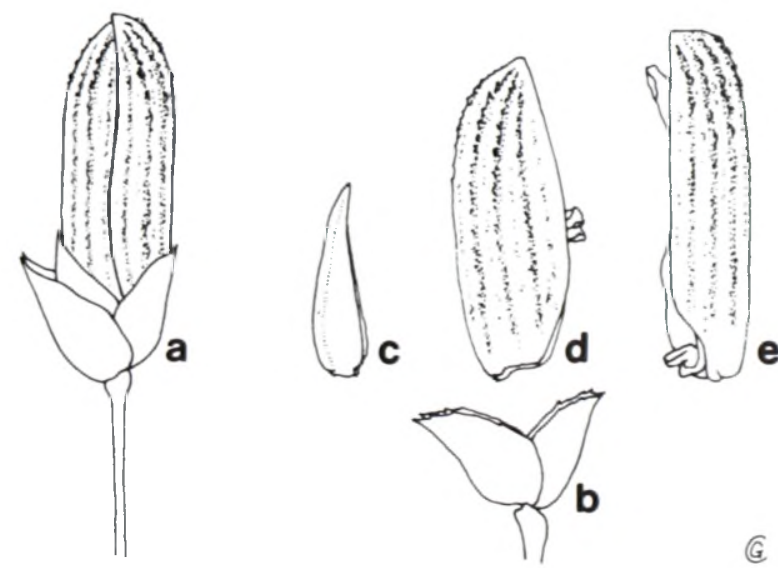

FIGURE 1.-Spikelet of $E$. rupestris subsp. tricostata: a, whole spikelet; b, glumes; c, first sterile lemma; d, fertile lemma; $e$, second sterile lemma (Esterhuysen 26708) (×6).

Within what is now regarded as the Setacea group, Nees (1841) recognized two species, and the fundamental difference of their spikelet plan from that of the rest of the genus was demonstrated by Steudel (1853). Stapf (1900) added three new species and a variety, but Gibbs Russell (1984) placed all of Stapf's taxa, plus an additional one, as subspecies within Nees's original two species. These decisions, based on macromorphology and spikelet morphology, are generally supported by 
anatomical studies (Ellis 1987). In most cases, anatomical characters have allowed better interpretation of confusing morphological states; in other cases, morphologi$\mathrm{cal}$ and anatomical evidence do not agree. Some of the variation in the Setacea group, where morphological and anatomical characters are contradictory, may be a result of convergent adaptations for tough, long-lived leaves often encountered in plants of the low-nutrient Fynbos soils.

In Africa, Ehrharta is a genus characteristic of the winter rainfall areas, and has its centre of diversity in Fynbos, but a number of species also occur in Succulent Karoo, Karoo, Savanna and Forest. Six of the species groups have taxa in more than one vegetation type. The Setacea group is unique in being restricted to Fynbos, and occurs only from the Cape Peninsula north to Worcester and east to Humansdorp.

\section{KEY TO SPECIES IN THE SETACEA GROUP}

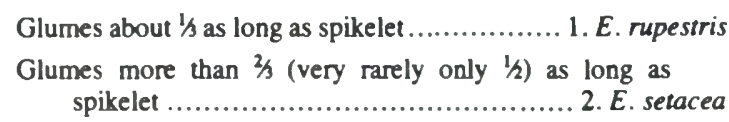

1. Ehrharta rupestris Nees ex Trin. in Mémoires de l'Académie impériale des Sciences de St-Pétersbourg, sér. 6,5: 25 (1839); Nees: 227 (1841); Stapf: 668 (1900); Chippind.: 37 (1955). Type: Cape Province, Caledon Distr., Gnadenthal, Drège (K, isosyn.!; SAM, isosyn.!; PRE, photo.!, fragment!).

\section{Trochera rupestris (Nees) Kuntze: 795 (1891).}

Erect or trailing tufted perennial with long creeping thizomes, of widely varying size and habit, from delicate herbaceous plants $100 \mathrm{~mm}$ tall to robust suffrutescent plants $450 \mathrm{~mm}$ tall. Culms erect or decumbent, branched and creeping at base, leafless below. Leaves with blades erect or spreading, inrolled, folded or flat; ligule a membrane fringed with hairs; sheaths overlapping. Inflorescence an erect raceme overtopping leaves. Spikelets 1-9, erect, often distichous. Glumes about $1 / 3$ length of entire spikelet, lower ones with tip truncate or rounded, upper ones acute. Florets with sterile lemmas dissimilar, the first sterile lemma a thin scale with 3-5 raised nerves, $1 / 3-1 / 2$ the length of second, often appearing to be a third glume; the second sterile lemma hard and thickened, with 7 minutely tubercled nerves, tip canoe-shaped; fertile lemma similar to second sterile lemma, but slightly shorter, broader and with more acute tip. Stamens 6. (a) subsp. rupestris. Gibbs Russell: 150 (1984).

Plants erect, robust, mat- or cushion-forming, to 300 $\mathrm{mm}$ tall, with strong woody thizomes. Culms suffrutescent, stiffly erect above. Leaves conspicuously distichous, with blades folded, usually held outward at about $45^{\circ}$, or sometimes erect, $20-30 \times 2-4 \mathrm{~mm}$, tips hooded; sheaths strongly overlapping, basal sheaths bladeless. Inflorescence of 4-8 spikelets, 15-35 mm long, overtopping leaves by at least 3 times its own length. Spikelets 4,5-6 mm long, to $2,5 \mathrm{~mm}$ across above glumes, oblong to almost square in outline

The folded leaf blades with hooded tips and the very broad spikelets separate this subspecies from all other taxa in the Setacea group. In spite of these morphological differences, anatomical characters support the combination of subsp. rupestris and subsp. tricostata under the same species (Ellis 1987).

The distribution of subsp. rupestris is shown in Figure 2. It is never common. It is most abundant and appears in its typical form in the Riviersonderend Mountains of the Caledon area. From there it extends northward and eastward, over the Langeberg at the Clock Peaks, and out along the dry Klein and Groot Swartberg, where the plants are smaller. In both the Caledon area and in the Klein Swartberg, where subsp. rupestris is sympatric with subsp. tricostata, intermediates in leaf and spikelet characters occur between the two subspecies.

The subspecies grows on mountain slopes among rocks at altitudes of 910 to $1970 \mathrm{~m}$. Flowering occurs from October to January.

A particularly robust specimen otherwise typical of the subspecies (Van Breda 4436) was collected on coastal sand in the Vanrhynsdorp region, well outside the usual distribution of the subspecies, and in a different habitat. Nevertheless, the anatomical characters closely resemble those of other examples of subsp. rupestris (Ellis 1987). There is some doubt about the correctness of the label of this specimen and its locality has not been plotted on Figure 2. A parallel example is known from $E$. calycina, in a different species group, where an extremely robust plant over $2 \mathrm{~m}$ tall was collected on coastal sand near Lambert's Bay (Gibbs Russell 5615).

Vouchers: Boucher 4201 (PRE, STE); Esterhuysen 21044 (BOL, PRE); Pocock S72 (PRE); Thomson 2255 (PRE); Van Breda 4436 (PRE).

(b) subsp. tricostata (Stapf) Gibbs Russell in Bothalia: 150 (1984).

Ehrharza tricostata Stapf: 669 (1900); Chippind.: 35 (1955). Type: Cape Province, French Hoek, 2400 feet, Schlechter 9292 (K, holo.!; PRE, iso.!).

\section{KEY TO SUBSPECIES}

la Plants delicate, herbaceous, less than $250 \mathrm{~mm}$ tall; inflorescence of $1-4$ spikelets, barely overtopping leaves; spikelets $4,5-5 \mathrm{~mm}$ long ....................................................... 1c. E. rupestris subsp. dodii

lb Plants \pm robust, herbaceous to suffrutescent, $200-450 \mathrm{~mm}$ tall; inflorescences of $4-9$ spikelets, considerably overtopping leaves; spikelets 4,5-6,3 mm long:

2a Leaf blades inrolled and appearing setaceous, erect, not distichous, or sometimes flat and \pm spreading, tips not hooded; spikelets (above glumes) to $2 \mathrm{~mm}$ across, linear to oblong ...................................

$2 \mathrm{~b}$ Leaf blades folded, somewhat thickened, distichous, usually at $45^{\circ}$ to culm, tips hooded; spikelets (above glumes) to $2,5 \mathrm{~mm}$ across, oblong to nearly square .............................. la. E. rupestris subsp. rupestris 


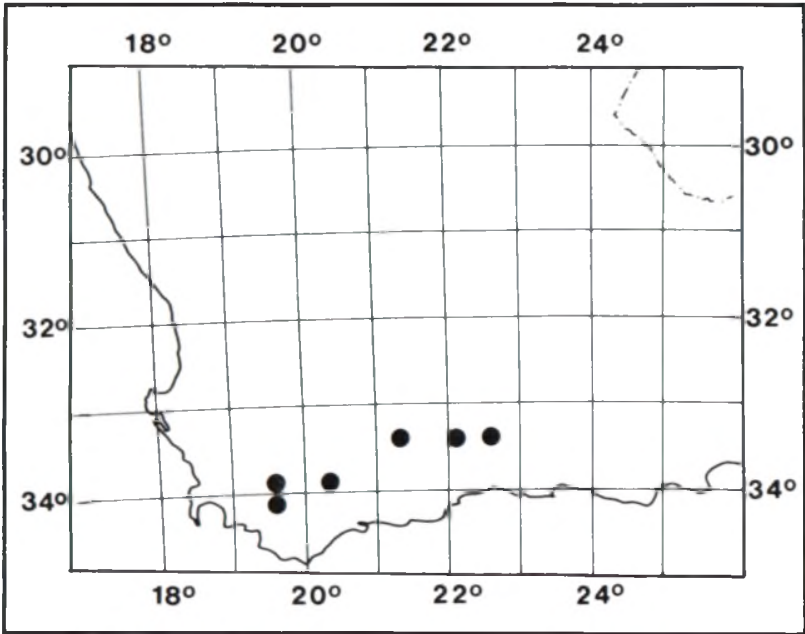

FIGURE 2.-Distribution of $E$. rupestris subsp. rupestris.

Plants erect, tufted, rarely trailing, $200-450 \mathrm{~mm}$ tall, with creeping rhizomes. Culms suffrutescent (rarely herbaceous). Leaves with baldes usually inrolled and appearing setaceous, often reduced, erect, or sometimes flat and spreading, not distichous, to $100 \times 2,5 \mathrm{~mm}$, tips tapering, acute; sheaths not strongly overlapping, basal leaves with blades. Inflorescence of 4-9 spikelets, 18-40 $\mathrm{mm}$ long, usually considerably overtopping leaves. Spikelets $4,6-6,3 \mathrm{~mm}$ long, to $2 \mathrm{~mm}$ across above glumes, oblong to linear.

In its size, erect habit, and relative abundance, this subspecies is similar to $E$. setacea subsp. setacea but it may be distinguished by the leaves at the base of the culm. E. rupestris subsp. tricostata has blade-bearing leaves nearly to the culm base, whereas $E$. setacea subsp. setacea has scale-like, overlapping, bladeless sheaths on the lower part of the culms.

The distribution of subsp. tricostata is shown in Fugure 3. It is the most common and the most widespread of all seven taxa in the Setacea group, extending from the mountains of the Peninsula north to the Hex River Mountains, and eastward to the Klein Swartberg and along the Outeniqua and Tsitsikama coastal ranges nearly to Humansdorp. The subspecies is not recorded from the Langeberg. Plants from the Peninsula and Caledon are the most robust and erect, with reduced setaceous leaf blades; plants from the easternmost end of the range are small and fine, although with suffrutescent culm bases; plants from the Hex River Mountains merge into subsp. dodii and are decumbent, herbaceous and have flat leaf blades. All these forms grade gradually into each other. In addition, intermediates link this subspecies with the other two, which might be considered extreme forms. It is clear on anatomical grounds (Ellis 1987) that the smaller form of subsp. tricostata from the eastern part of the range is distinct from the small subsp. dodii, even though they overlap in size.

The subspecies grows in wet places on mountain slopes and at the base of cliffs, at altitudes of 300-2 030 $\mathrm{m}$. Flowering extends from October to February, with most plants flowering in November and December.

Vouchers: Ellis 2547 (PRE); Esterhuysen 28594 (BOL, PRE, STE); 32813 (BOL, PRE, STE); 33057 (BOL, PRE, STE); Fourcade 3132 (BOL, PRE, STE).

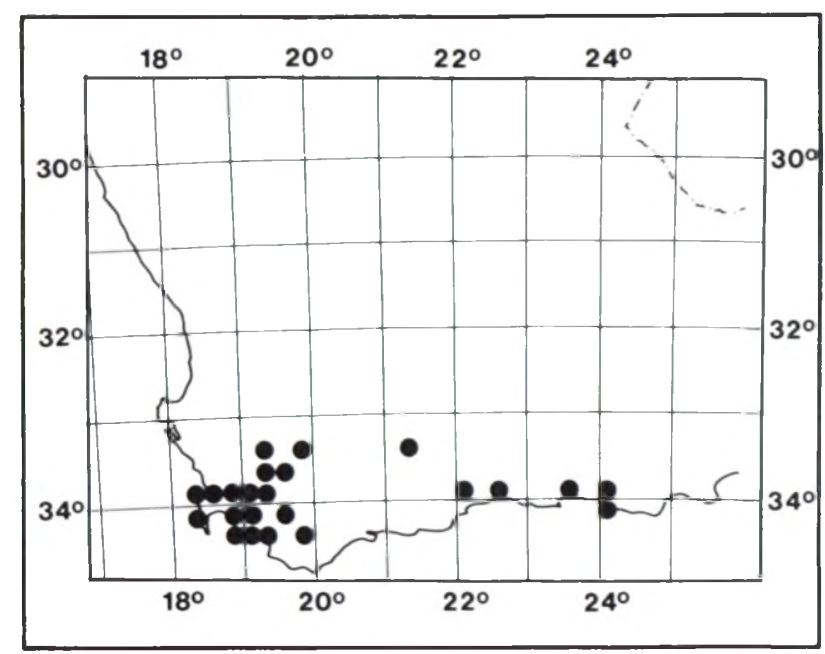

FIGURE 3.-Distribution of $E$. rupestris subsp. tricostata.

(c) subsp. dodii (Stapf) Gibbs Russell in Bothalia: 150 (1984).

Ehrharta dodii Stapf: 670 (1900); Chippind.: 35 (1955). Type: Cape Province, rocks on Constantia Berg. Wolley Dod 1961 (K, holo.!; BOL, iso.!; PRE, photo.!, fragment!).

Differs from subsp. tricostata mainly in size, habit and in number of spikelets. Plants are less than $250 \mathrm{~mm}$ tall, trailing or rarely erect, and rhizomes, culms, and leaves are herbaceous and delicate, with the culms freely branched and the leaf blades inrolled and held erect. Inflorescence of 1-4 spikelets, 5-10 mm long, barely overtopping leaves. Spikelets $4,5-5 \mathrm{~mm}$ long, to $2 \mathrm{~mm}$ across above glumes.

This subspecies is difficult to distinguish except on glume length from the two small, delicate subspecies of $E$. setacea. In general, $E$. rupestris subsp. dodii is trailing or erect, with erect rolled leaf blades, whereas $E$. setacea subsp. uniflora is also trailing, but usually has flat leaf blades, and $E$. setacea subsp. disticha is erect with spreading, rolled or folded leaf blades. However, in each taxon the habit is variable to some extent.

The distribution of subsp. dodii is shown in Figure 4. It has the most restricted range of any subspecies of $E$. rupestris, occurring only from Constantia Berg on the Peninsua around to Kogelberg, and northward through Hottentots Holland and Franschhoek to the Hex River Mountains. It is connected in the eastern part of its range to subsp. tricostata by intermediates of slightly larger stature, upright habit and with more numerous spikelets. These occur within the range of typical subsp. dodii as well as to the east as far as Montagu. The lax Hex River Mountain form of subsp. tricostata should perhaps be counted among these intermediates.

The subspecies grows in wet places on mountainsides among rocks and at the bases of cliffs, at altitudes of $660-1660 \mathrm{~m}$. Flowering occurs from November to early January.

Vouchers: Boucher 2039 (PRE, STE); Ellis 2286 (PRE); Esterhuy sen 33065 (BOL, PRE); 33084 (BOL, JF, PRE); 34169 (BOL, PRE). 


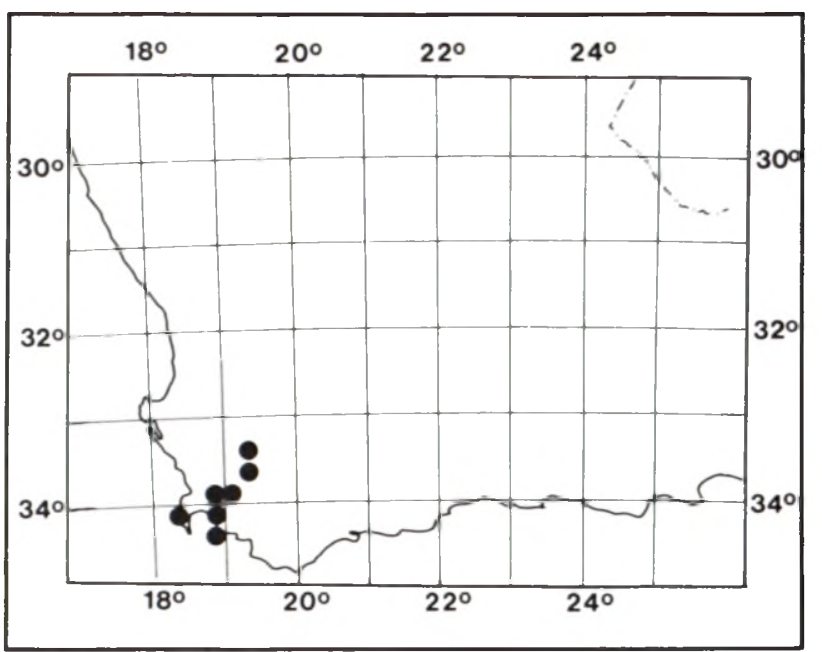

FIGURE 4.-Distribution of $E$. rupestris subsp. dodii.

2. Ehrharta setacea Nees, Florae Africae Australioris: 228 (1841). Stapf: 668 (1900); Chippind.: 37 (1955). Type: Cape Province, in monte tabulari, alt. $3000 \mathrm{ft}$, Drège (PRE, isosyn., fragment!).

Erect or trailing tufted perennials with long creeping rhizomes, sometimes stoloniferous, of widely varying size and habit, from delicate herbaceous plants $100 \mathrm{~mm}$ tall to robust suffrutescent plants $600 \mathrm{~mm}$ tall. Culms decumbent or prostrate, suffrutescent or herbaceous, often leafless below. Leaves with blades erect, recurved or spreading, inrolled, folded or flat; ligule a membrane fringed with hairs; sheaths overlapping. Inflorescence an erect raceme barely to considerably overtopping leaves. Spikelets 1-15, at first erect but spreading at anthesis. Glumes $2 / 3$ (very rarely only $1 / 2$ ) as long as to longer than lemmas, both acute. Florets as in E. rupestris.

\section{(a) subsp. setacea. Gibbs Russell: 150 (1984).}

Plant erect, 250-400 mm tall. Culms suffrutescent, branched near base, bare of leaves below, sometimes with much shortened inflated side branches. Leaves with blades hard, smooth, usually tightly inrolled and appearing setaceous, straight and erect or curved outward and spreading from the middle, 50-80 (110) $\times 4 \mathrm{~mm}$; sheaths overlapping at upper internodes, basal sheaths without leaves, yellowish, truncate, slightly spreading. Inflorescence of 5-15 spikelets, 25-60 mm long, usually overtopping leaves by at least its own length. Spikelets 5,5-6,8 mm long, oblong; glumes $2 / 3$ as long as, to longer than spikelet, not gaping at maturity.
This subspecies is most similar in habit and size to $E$. rupestris subsp. tricostata, but that taxon has blade-bearing sheaths at the lowest culm nodes, while $E$. setacea subsp. setacea has conspicuous pale, bladeless, squaretopped sheaths at the lower nodes of the culm. Leaf anatomical features (Ellis 1987) suggest that the two taxa might be united. However, each is linked by intermediates to different but parallel lines of morphological variation. The anatomical similarity, which extends even to species in unrelated genera, is an example of convergence in leaf characters common in Fynbos. It is noteworthy that the two taxa with this typical 'Fynbos anatomy' are the most widespread subspecies in the Setacea group.

The distribution of subsp. setacea is shown in Figure 5. It is the western element of $E$. setacea, and is the most widespread of the four subspecies, occurring from the Cape Peninsula north to Baines Kloof and east only as far as the Hottentots Holland and Kogelberg Mountains. In the Klein Rivier Mountains and at Betty's Bay in the Caledon District it is linked to subsp. uniflora and subsp. disticha by intermediates of smaller size and semi-herbaceous habit.

The subspecies grows on mountainsides in damp, peaty or marshy places and in seepage areas, either in shale or in sand derived from Table Mountain Sandstone, at altitudes of $660-1515 \mathrm{~m}$. Flowering occurs from September to December and sporadically until April.

Vouchers: Esterhuysen 3574 (BOL, NBG, PRE); 26501 (PRE); 28669 (BOL, PRE, STE); 33245 (BOL, PRE); Wolley Dod 3334 (BOL, PRE).

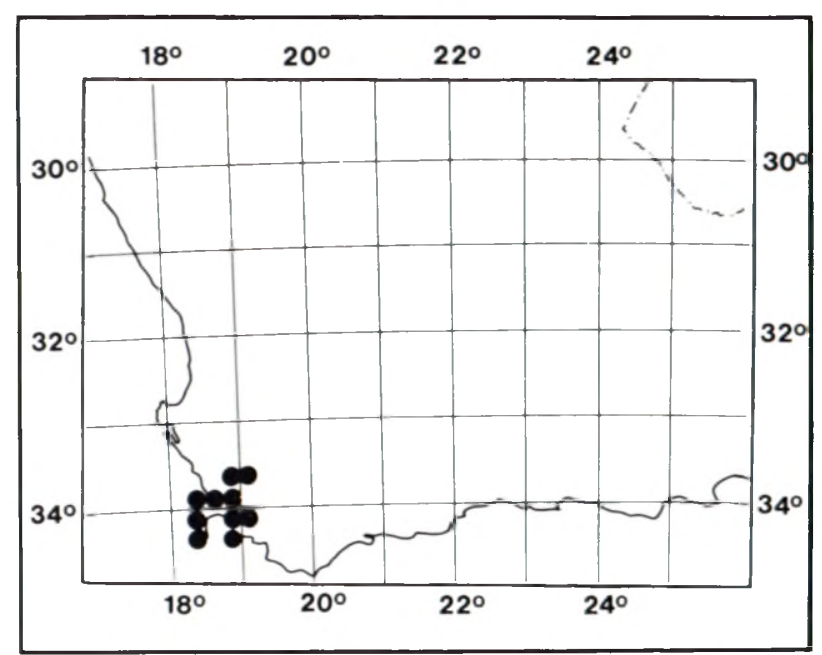

FIGURE 5.-Distribution of E. setacea subsp. setacea.

\section{KEY TO SUBSPECIES}

la Plants $250-400 \mathrm{~mm}$ tall, erect; inflorescences of 5-17 spikelets; glumes appressed to florets at maturity:

2a Leaf blades smooth, tightly rolled, appearing setaceous, rigid, erect, straight or curved slightly outward from middle; spikelets $5,5-6,8 \mathrm{~mm}$ long ...............................................2a. E. setacea subsp. setacea

2b Leaf blades scabrous, flat and broad (to $6 \mathrm{~mm}$ across) at base, rolled near tip, bent $45^{\circ}$ outward from culm at sheath; spikelets $(6,5) 7-8 \mathrm{~mm}$ long.............................................2b. E. setacea subsp. scabra

1b Plants shorter than $250 \mathrm{~mm}$, sprawling or erect; inflorescences of $1-4$ spikelets; glumes gaping widely (more than $45^{\circ}$ ) at maturity:

3a Plants trailing or sprawling, culms herbaceous, lowest nodes bearing leaves with blades; spikelets 4,5-6 mm long; glumes usually slightly longer than lemmas ................................2c. E. setacea subsp. uniflora

3b Plants erect, cushion-forming, culms suffrutescent at base, lowest nodes usually leafless; spikelets $4-5 \mathrm{~mm}$ long; glumes usually slightly shorter than lemmas ..... 
(b) subsp. scabra (Stapf) Gibbs Russell in Bothalia: 151 (1984).

Ehrharta setacea Nees var. scabra Stapf: 669 (1900). Type: Cape, in a mountain peak near Swellendam, Swellendam Div., Burchell 7312 (K, holo.!; PRE, photo.!).

Plant erect, $250-600 \mathrm{~mm}$ tall, stoloniferous. Culms suffrutescent, branched near base, sometimes with much shortened side branches. Leaves with blades scabrous, flat at base, rolled near tip, held $45^{\circ}$ from culm at sheath, to $30-110 \times 6 \mathrm{~mm}$; sheaths overlapping. Inflorescence of 5-17 spikelets, 30-55 $\mathrm{mm}$ long, overtopping leaves by at least twice its own length. Spikelets $(6,5) 7-8 \mathrm{~mm}$ long, oblong; glumes $2 / 3-3 / 4$ as long as lemmas, not gaping at maturity.

This subspecies is easily distinguished from all other African Ehrharta species by the scabrous leaf blades, with a texture resembling that of a Melica or a Leersia. Anatomically, subsp. scabra and subsp. setacea differ considerably (Ellis 1987), raising the question whether they should be treated as separate species. Despite their anatomical differences and the absence of intermediates between the two allopatric entities, they were kept as subspecies because of the confused situation in the Caledon area, where intermediates occur between subsp. setacea and subsp. scabra to both subsp. uniflora and subsp. disticha.

The distribution of subsp. scabra is shown in Figure 6 . It occurs only along the Langeberg from the Clock Peaks above Swellendam to Garcia's Pass, and thus forms the eastern element of $E$. setacea. In the Caledon area, it is linked through a number of intermediates to subsp. disticha and subsp. uniflora.

The subspecies grows mostly in disturbed places on mountainsides, such as path sides and burned clearings, and also among rocks in seepage areas, at altitudes of $350-1212 \mathrm{~m}$. Flowering occurs from October to January and sporadically to March.

Vouchers: Crook 2268 (PRE); Du Toit 2040 (PRE, STE); Haynes 868 (JF, PRE, STE); Taylor 4236 (PRE, STE); 7613 (PRE, STE).

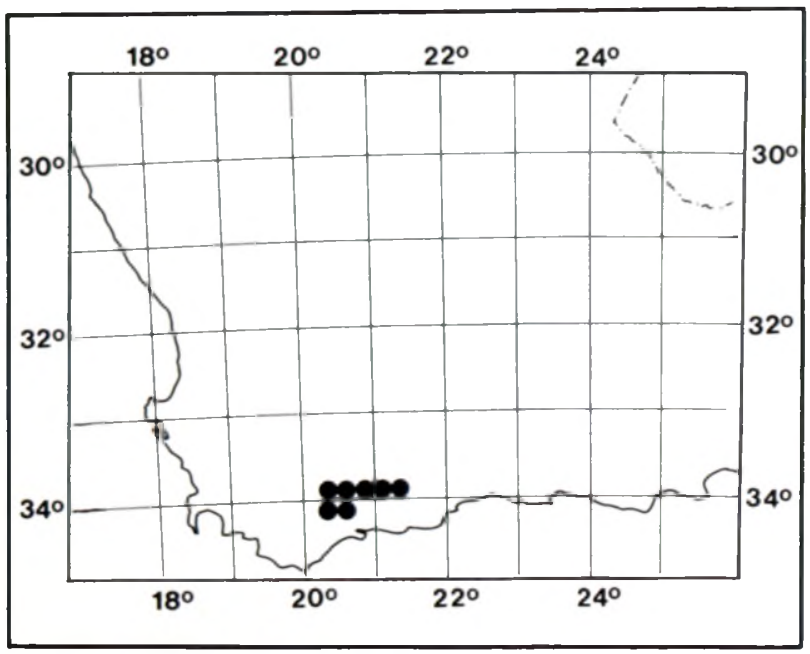

FIGURE 6.-Distribution of $E$. setacea subsp. scabra.

(c) subsp. uniflora (Burch. ex Stapf) Gibbs Russell in Bothalia: 151 (1984).

Ehrharta uniflora Burch. ex Stapf: 670 (1900); Chippind.: 37 (1955). Type: Cape, Cape Flats near Rondebosch, Burchell 182 (K, holo.!; PRE, fragment!).
Plants sprawling or trailing, delicate but forming dense masses. Culms fine, herbaceous, freely branched, lowest nodes bearing leaves with blades. Leaves not distichous, blades soft, flat, straight, $50-80 \times 2 \mathrm{~mm}$; sheaths barely or not overlapping. Inflorescence of 1-4 spikelets, 5-14 mm long, barely overtopping leaves. Spikelets 4,5-6,5 mm long; glumes usually slightly longer than lemmas but sometimes slightly shorter, gaping more than $45^{\circ}$ at maturity.

This subspecies can be distinguished from the other two small taxa in the Setacea group by its long glumes (E. rupestris subsp. dodii has short glumes) or trailing habit ( $E$. setacea subsp. disticha is erect).

The distribution of subsp. uniflora is shown in Figure 7. It is known only around False Bay, from the Cape Peninsula to Pringle Bay. In the Caledon District intermediates occur to subsp. setacea and subsp. scabra.

The subspecies grows in seepage areas, marshy places and along watercourses, as well as at forest margins. It is the only taxon in the Setacea group to occur at low altitudes, from 10-500 m. Flowering occurs from September to December, and occasionally to March.

Vouchers: Adamson 1331 (BOL, PRE); Cleghorn 3168 (PRE, STE); Esterhuysen 34002 (BOL, PRE); 34039 (BOL, NBG, PRE).

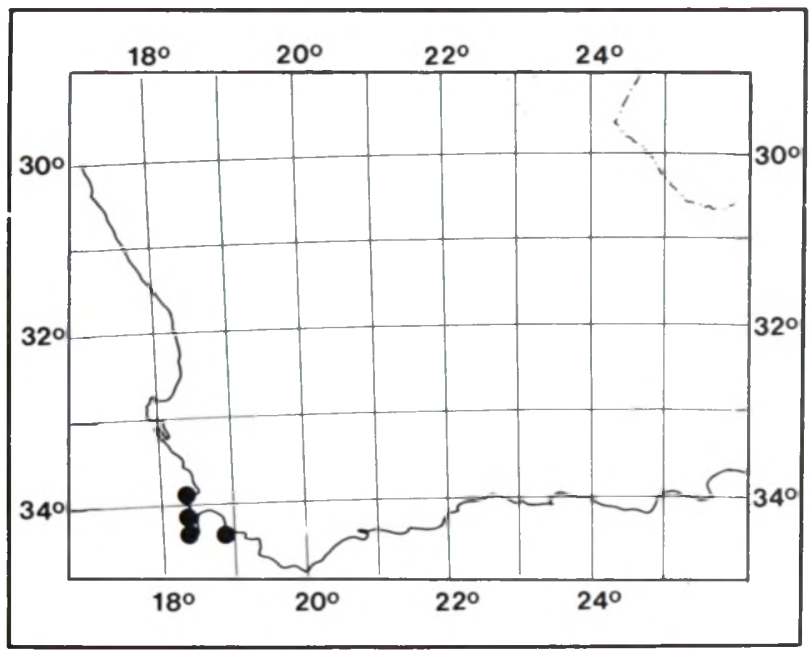

FIGURE 7.-Distribution of $E$. setacea subsp. uniflora.

(d) subsp. disticha Gibbs Russell in Bothalia: 151 (1984). Type: Cape, Caledon District, Maanschynkop, Rocklands Park, Esterhuysen 31735 (PRE, holo.!; BOL, iso.!).

Plant erect, cushion-forming, to $250 \mathrm{~mm}$ tall, differing from subsp. scabra mainly in size, number of spikelets and position of glumes. Culms branched near base, suffrutescent, lowest nodes usually leafless. Leaves distichous, blades hard, rolled, recurved or erect, to $30 \mathrm{~mm}$ long. Inflorescences of 1 or 2 spikelets, 5-10 mm long, barely overtopping leaves. Spikelets 4-5 mm long; glumes slightly shorter than lemmas, gaping more than $45^{\circ}$ at maturity.

This small subspecies is separated from short-glumed $E$. rupestris subsp. dodii by its long glumes, and from lax $E$. setacea subsp. uniflora by its erect habit and generally smaller spikelets with glumes slightly shorter than the spikelet. 
The distribution of subsp. disticha is shown in Figure 8. It is known only from the Babylon's Tower and Klein River Mountains of the Caledon area. A number of intermediate specimens show that in this area it intergrades with subsp. setacea and subsp. scabra.

The subspecies grows in dry rocky places on mountain slopes, at altitudes of $580-1225 \mathrm{~m}$. All other taxa in the Setacea group grow in damp or wet places. The striking habit difference between subsp. disticha and subsp. uniflora may result from adaptation of the former to water stress in a dry habitat. Flowering occurs in October and November.

Vouchers: Esterhuysen 31735 (BOL, PRE); 32319 (BOL, PRE); 33647 (BOL, PRE); 34755 (BOL, PRE); Williams 3086 (NBG, PRE).

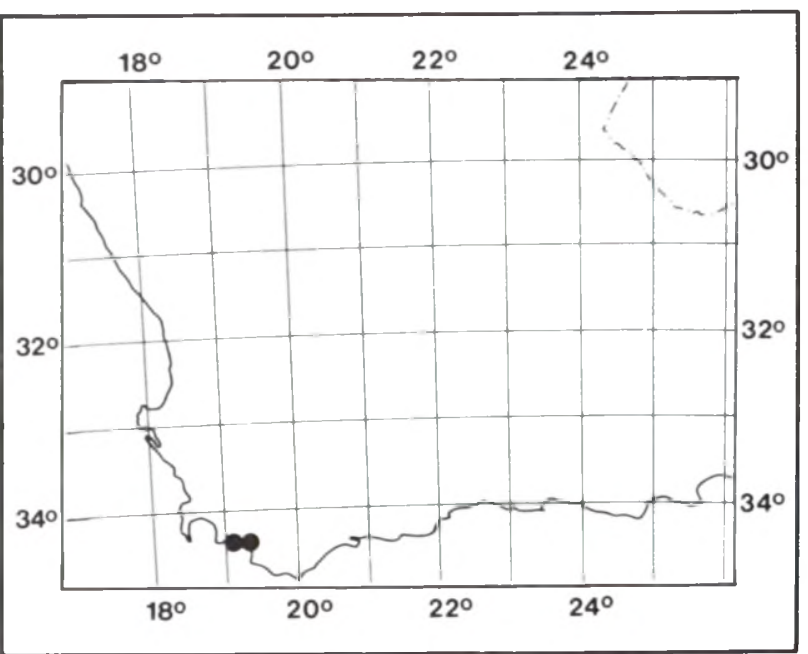

FIGURE 8.-Distribution of $E$. setacea subsp. disticha.

\section{CONCLUSION}

The Setacea group is composed of very closely related taxa, as shown by both morphological and anatomical characters. These taxa are distinguished from other Ehrharta species by the spikelet plan, with a short first sterile lemma, and by a number of anatomical features. These distinctive characteristics indicate that the Setacea group must be carefully reviewed when generic limits in the Ehrharteae are examined. The Setacea group has a more restricted distribution than any other group in the genus. All the subspecies except $E$. setacea subsp. scabra occur in the Caledon degree grid (3419), and examples of all the intermediates also occur in this degree grid. Thus, the Setacea group is concentrated in the south-western phytogeographical centre of Weimarck (1941) and the smaller south-western centre of Oliver $e t$ al. (1983). Outside this pivotal area, each taxon has a distinctive distribution. Only one subspecies occurs throughout the range of the group, $E$. rupestris subsp. tricostata. The other subspecies show vicariant distribution, limited to particular mountain ranges.

Although they are very similar, the seven infraspecific taxa recognized here are each distinguished by macromorphological, spikelet and anatomical differences. The occurrence of intermediates links them into two groups with parallel morphological trends, as shown in Table 1. These two groups are treated as separate species, with the linked entities which they comprise treated as subspecies. In each species, the most widespread and commonly collected subspecies is a robust plant with hard setaceous leaves: $E$. rupestris subsp. tricostata and $E$. setacea subsp. setacea. Each species has a robust subspecies of more restricted eastern distribution differentiated from the widespread one by broader spreading leaf blades and larger spikelets: $E$. rupestris subsp. rupestris and $E$. setacea subsp. scabra. Each species has little delicate subspecies with reduced inflorescences and small spikelets in the Peninsula and Caledon area: $E$. rupestris subsp. dodii, $E$. setacea subsp. uniflora and $E$. setacea subsp. disticha. Each of these reduced taxa has a distinctive habitat. $E$. rupestris subsp. dodii grows in wet places at high altitudes, $E$. setacea subsp. uniflora grows in wet places at low altitudes, and $E$. setacea subsp. disticha grows in dry places at high altitudes. Thus, the factors in the Caledon area that favour small size are apparently independent of moisture regime and altitude.

\section{AKNOWLEDGEMENTS}

I thank: the Directors of herbaria that have lent specimens, Bolus Herbarium (BOL), University of Cape Town; Moss Herbarium (J), University of the Witwatersrand, Johannesburg; Wicht Herbarium (JF), Jonkershoek Forestry Research Centre; The Herbarium, Royal Botanic Gardens, Kew (K); National Botanic Garden, Kirstenbosch (NBG \& SAM); Botanical Research Unit, Stellenbosch (STE). Also R. P. Ellis and W. D. Clayton for profitable discussions, G. Condy for the spikelet drawing, and especially W. Roux for technical assistance and preparation of diagrams.

\section{REFERENCES}

CHIPPINDALL, L. 1955. A guide to the identification of grasses in South Africa. In C. Meredith, The grasses and pastures of South Africa. Central News Agency, Cape Town.

ELLIS, R. P. 1987. Leaf anatomy of the genus Ehrharta (Poaceae): the Setacea group. Bothalia 17: 75-89.

TABLE 1.-Parallel trends in subspecies for the two species of the Setacea group. Arrows indicate the existence of specimens intermediate between subspecies

Adaptation and distribution

E. rupestris
Plant large. robust; leaves setaceous, erect: widespread distribution
Plant small;

leaves delicate:

'False Bay' distribution
Plant large, robust;

leaves broad, spreading:

'Eastern' distribution 
GIBBS RUSSELL, G. E. 1984. Notes on species of Ehrharta with a shor first sterile lemma (Poaceae). Bothalia 15: 149-151.

GIBBS RUSSELL, G. E. \& ELLIS, R. P. 1987. Species groups in the genus Ehrharia (Poaceae) of southem Africa. Bothalia 17: 51-65.

KUNTZE, C. E. O. 1891. Revisio generum plantarum. Felix, Leipzig.

NEES AB ESENBECK, C. G. 1841. Florae Africae Australioris. Prausnitzianus, Cracow.

OLIVER, E. G. H., LINDER, H. P. \& ROURKE, J. P. 1983. Geographical distribution of present-day Cape taxa and their phytogeographical significance. Bothalia 14: 427-440.

STAPF, O. 1900. Gramineae. In W. T. Thiselton-Dyer, Flora capensis 8 : $310-750$.

STEUDEL, E. G. 1853. Synopsis plantarum graminearum. Metzler, Stuttgart.

TRINIUS, C. B. 1839. Phalarideae. Mémoires de l'Académie impériale des Sciences de St-Pétersbourg, sér. 6, 5: 12-26.

WEIMARCK, H. 1941. Phytogeographical groups, centres and intervals within the Cape flora. Lunds Univertsitets Arsskifi 37, 5: $1-143$.

\section{SPECIMENS EXAMINED}

Adamson 596 (2a) BOL; 616 (2a) PRE; 660 (2a) BOL; 1331 (2c) PRE, BOL. Andreae 1283 (1b) PRE.

Bews 15169 (2a) BOL. Bolus 7978 (1b/2a) BOL; 33866 (2a) PRE. Bond 668 (1b) NBG. Boucher 2039 (1c) K, PRE. STE; 2069 (1b) PRE, STE; 2642 (2a) STE; 2645 (1c) K, STE; 4201 (1a) PRE. STE. Burchell 182 (2c) K, PRE; 7312 (2b) K. PRE; 7419 (1a) K

Cleghorn 3168 (2c) PRE, STE; 3174 (2a/2c) K, PRE, STE. Compton 15486 (2a) NBG; 17505 (2a) NBG. Crook 2268 (2b) K. PRE.

Drège 1659 (2a) PRE; 1661 (1a) K, PRE; 19358 (1a) SAM. Du Toit 2040 (2b) PRE, STE.

Ellis 1678 (2b) PRE; 1679 (2b) PRE; 2273 (2a) PRE; 2286 (1c) PRE; 2287 (1c) PRE; 2294 (2a) PRE; 2544 (2b) PRE; 2547 (1b) PRE; 4652 (2b) PRE; 4653 (2b) PRE; 4669 (2b/2c) PRE; 4670 (2b/2c) PRE; 4679 (2a) PRE; 4685 (1a) PRE; 4689 (2b) PRE; 4690 (1b) PRE; 4700 (1b) PRE. Esterhuysen 1541 (1b) BOL; 3574 (2a) BOL, NBG, PRE; 6770 (1b) BOL, NBG, PRE, SAM; 9498 (2a) BOL; 10876 (1b) BOL; 10974 (1c) BOL; 21044 (1a) BOL, PRE; 22354 (2a) BOL, PRE; 22676 (1c) BOL, PRE; 24081 BOL, PRE; 26501 (2a) PRE; 26708 (1a/1b) BOL, PRE; 27368 (1b) BOL, PRE; 27558 (2b/2c) BOL, K, PRE; 28067 (2a)
BOL, PRE; 28109 (1b) BOL, K, NBG, PRE; 28267 (1b) PRE; 28594 (1b) BOL, K, PRE, STE; 28619 (1b/1c) BOL, K, PRE; $28651 a$ (lc) BOL, K; 28669 (2a) BOL, K, PRE, STE; 28683 (2b/2c) BOL, K; 28712 (lb) BOL, K, PRE, STE; 28777 (2b) BOL, K, PRE; 29936 (2b/2c) BOL, K, PRE, STE; $30045 a(2 \mathrm{c}) \mathrm{BOL} ; 31424(2 \mathrm{~b} / 2 \mathrm{c}) \mathrm{BOL}$, K; 31735 (2d) BOL, PRE; 32319 (2d) BOL, K, PRE; 32553 (2a) BOL; 32727 (1c) BOL, K, PRE; 32792 (1b) BOL, K, PRE; 32813 (lb) BOL, K, PRE, STE; 33040 (2c) BOL, PRE; 33047 (1b) BOL, K, PRE; 33056 (2c) BOL, PRE, STE; 33057 (1b) BOL, K, PRE, STE; 33065 (1c) BOL, K, PRE; 33084 (1c) BOL, JF, K. PRE; 33150 (1b) BOL; 33245 (2a) BOL, PRE; 33299 (1b/lc) BOL; 33511 (1c) BOL, PRE; 33520 (lb) BOL, K; 33523 (lb) BOL, PRE; 33647 (2d) BOL, K, PRE; 33662 (2a/2c) BOL, PRE; 33724 (2c) BOL, PRE; 33733 (1c) BOL, K; 33762 (1b) BOL, K; 34002 (2c) BOL, PRE; 34039 (2c) BOL, NBG, PRE; 34122 (1b) BOL, K, PRE; 34168 (lb/1c) BOL, PRE; 34169 (1c) BOL, K, PRE; 34173 (1b) BOL, K, PRE; 34183 (1b) BOL, K; 34497 (1c) BOL, K; 34505 (1b) K, PRE; 34557 (lb) BOL, K; 34755 (2d) BOL, K, PRE; 34778 (2a) BOL; 34834 (1b) BOL, PRE; 35300 (1b) BOL, K, PRE; 35364 (1a) BOL, K; 35539a (2d) BOL, K; 35571 (1b) BOL; 35620 (lb) BOL; 35621 (1a) BOL; 35733 (1b) BOL; 35812 (1c) BOL; 35822 (2a) BOL; 35835 (1b) BOL.

Forsyth 355 (2a) JF. Fourcade 3132 (1b) BOL, K, PRE, STE.

Galpin 164 (2a/2c) PRE, STE. Gibbs Russell 5634 (2b) BOL, K, NBG, PRE; 5635 (2b) BOL, K, PRE; 5652 (2b/2c) BOL, K, NBG, PRE; 5671 (2a) BOL, K, NBG, PRE; 5671 a (1c) PRE; 5675 (1c) PRE; 5676 (1a) BOL, K, NBG, PRE; 5678 (1a) PRE; 5682 (2b) BOL, K, NBG, PRE; 5696 (1b) BOL, K, NBG, PRE.

Haynes 868 (2b) JF, PRE, STE.

Kerfoot 5709 (1b) JF. Kruger 276 (1b) JF; 521 (2a) JF, PRE; 651 (1c) JF; 1099 (1b) JF, STE; 1515 (1b) JF, STE; 1599 (1c) JF.

Pappe 53 (2a) PRE. Pocock 572 (1a) PRE.

Schlechter 1825 (2b) BOL, K; 9292 (1b) BOL, K, PRE; 9869 (1a/lb) BOL, K, PRE. Stokoe 2537 (1b/1c) PRE: 7810 (2a) BOL; 8640 (la) BOL; 22547 (1b) BOL; 67667 (2a) SAM; 67675 (1a) SAM.

Taylor 3222 (2b) PRE, STE; 4236 (2b) PRE, STE; 7613 (2b) K, PRE, STE; 7668 (2c) PRE. Thompson 1597 (1b) PRE. STE; 2255 (1a) PRE. Thorne 43440 (2b) SAM: 44556 (1a) SAM; 45847 (1a) SAM. Van Breda 4436 (1a) PRE. Van der Merwe 25-52 (2a) PRE; 933 (2a) PRE, STE; 934 (2a) PRE, STE. Van Rensburg 215 (2a) PRE.

Williams 2887 (2d) NBG; 2963 (1b) K, NBG, PRE; 3015 (1b) K, NBG PRE; 3086 (2d) K, NBG, PRE; 3150 (2b/2d) K. Wolley Dod 1961 (1c) BOL, K, PRE; 3334 (2a) BOL, K, PRE.

Zeyher 19359 (2a) SAM. 